\title{
UPAYA MENINGKATKAN KEMAMPUAN MENULIS TEKS HASIL OBSERVASI MELALUI PENERAPAN E - LEARNING SISWA KELAS VII SMP NEGERI 1 NGANJUK
}

\author{
Rr ERY KUSUMA INDRYATI \\ SMPN 1 Nganjuk, Jawa Timur \\ E-mail: erykusumaa@gmail.com
}

\begin{abstract}
ABSTRAK
Penyebab utama rendahnya nilai Bahasa Indonesia dari faktor guru adalah kurang variasinya metode yang digunakan dalam pembelajaran sehingga siswa mengalami hambatan dalam memahami materi pelajaran.Tujuan penelitian tindakan kelas ini adalah: (1) Untuk mendeskrisikan kemampuan menulis teks hasil observasi pada siswa Kelas VII SMP Negeri 1 Nganjuk melalui E-Learning; dan (2) Untuk mendeskripsikan aktivitas belajar siswa Kelas VII SMP Negeri 1 Nganjuk setelah adanya pembelajaran dengan E-Learning. E-Learning adalah sistem pendidikan yang menggunakan aplikasi elektronik untuk mendukung belajar mengajar dengan media internet, jaringan komputer, maupun komputer standalone (Learn Frame.Com, 2011).Berdasarkan hasil penelitian didapat kesimpulan bahwa: (1) Melalui penerapan E - Learning, maka kemampuan menulis teks hasil observasi pada Siswa Kelas VII SMP Negeri 1 Nganjuk dapat meningkat dari sebelumnya.; (2) Peningkatan kemampuan menulis teks hasil observasi sampai pada siklus II dapat dilaporkan bahwa: (1) Nilai rata-rata kelas mencapai 81,56; (2) Persentase keberhasilan siswa mencapai 93,75\%; (3) Persentase keberhasilan aktivitas siswa mencapai 93,3\% ; dan (3) E-Learning dapat meningkatkan aktivitas belajar siswa Kelas VII SMP Negeri 1 Nganjuk
\end{abstract}

Kata Kunci : Teks LHO, Penerapan E-learning

\section{PENDAHULUAN}

Arikunto (2016: 130) mengemukakan bahwa dalam proses pembelajaran, guru memegang peranan yang sangat penting, di samping unsur-unsur yang lain seperti konteks, siswa, kurikulum, metode, dan sarana. Keenam unsur ini dapat berpengaruh terhadap kualitas pembelajaran, namun unsur guru dinilai merupakan unsur yang mampu mengubah unsurunsur lain menjadi bervariasi.

Dalam proses belajar mengajar, perbaikan belajar ini penting sekali artinya bagi siswa. Tanpa adanya program perbaikan belajar ini, anak yang kurang mampu akan selamanya tertinggal dari teman-temannya, dan anak yang pintar mungkin akan menyalurkan kemampuannya yang berlebih pada hal-hal yang negatif. Penerapan metode pengajaran upaya maksimal telah dilakukan oleh guru, misalnya menyampaikan materi dengan metode mengajar yang sesuai, menerapkan alat peraga pembelajaran, serta pemberian tugas yang dilakukan secara bertahap, namun demikian masih banyak siswa yang belum mampu menyerap materi pelajaran dengan semaksimal mungkin, yang ditunjukkan dengan pencapaian prestasi belajarnya yang rendah (Fanny: 2019). Di samping itu dalam proses pembelajaran, seringkali aktivitas siswa tidak muncul. Misalnya jika guru menyuruh siswa untuk bertanya tentang sesuatu materi pelajaran yang belum dipahaminya, maka dapat dipastikan sangat jarang siswa yang mengajukan pertanyaan, apalagi jika guru mengajukan pertanyaan kepada mereka, hampir dipastikan "sangat jarang" siswa yang mau menjawabnya. Sehingga pembelajaran yang aktif, kreatif dan menyenangkan belum tercipta dengan baik.

Hal ini menjadi fenomena yang sangat biasa dialami oleh guru dalam setiap pembelajaran rutin di sekolah khususnya mata pelajaranm bahasa Indonesia. Untuk memberikan kesempatan berkembang yang wajar bagi anak di luar rata-rata ini, seorang guru perlu memiliki kemampuan dan keterampilan untuk melaksanakan diagnosis dan perbaikan belajar (Nasution, 2003). 
Di Sekolah Menengah Pertama, khususnya di SMP Negeri 1 Nganjuk melalui pengembangan berfikir kritis dan logis sangat berkaitan dengan upaya melibatkan siswa aktif dalam pembelajaran bahasa Indonesia. Dalam pelaksanaannya sebagai salah satu metode ELearning menawarkan kesempatan kepada siswa untuk terlibat secara aktif dalam proses perolehan pengetahuan.

Sebelum penelitian ini terjadi, bukti empiris menunjukkan bahwa salah satu nilai ulangan harian Bahasa Indonesia (semester 1) khususnya menulis teks hasil observasi yang diperoleh siswa dari 32 siswa hanya mencapai 66,56 dengan persentase keberhasilan baru mencapai $25 \%$ (masih di bawah rata-rata standar). Ini berarti masih jauh dari nilai standar hasil yang harus dicapai dalam ketuntasan, yakni 75,00 dengan persentase keberhasilan minimal $85 \%$.

Rendahnya prestasi belajar bahasa Indonesia, khususnya dalam kemampuan menulis teks hasil observasi tersebut berakibat pula pada penurunan hasil belajar bahasa Indonesia secara umum. Hal ini disebabkan oleh beberapa faktor, antara lain: (1) Perhatian siswa terhadap materi menulis minim sekali; (2) Siswa cenderung mencontoh tulisan temannya yang sudah dianggap bisa; (3) Siswa kurang senang belajar bahasa Indonesia yang hanya model ceramah saja; dan (4) Guru jarang melatih siswa untuk menulis puisi maupun pantun. Menurut Hartanto (2016), E-learning merupakan inovasi yang dapat digunakan dalam proses pembelajaran, tidak hanya untuk materi pembelajaran tetapi juga untuk mengubah berbagai kompetensi siswa. Melalui e-learning, peserta didik tidak hanya mendengarkan materi diskusi dari pendidik tetapi juga aktif dalam mengamati, melakukan, demo, dan sebagainya.

Dari kenyataan di atas terlihat bahwa peningkatan Prestasi Belajar Bahasa Indonesia (Materi Pokok menulis teks hasil observasi) bagi siswa kelas VII SMP Negeri 1 Nganjuk perlu diteliti. Untuk itu dalam penelitian ini peneliti mencoba menerapkan E-Learning dalam rangka peningkatan hasil belajar bahasa Indonesia tersebut, sehingga penelitian ini diberi judul Upaya Meningkatkan Kemampuan Menulis teks hasil observasi melalui Penerapan ELearning Siswa Kelas VII SMP Negeri 1 Nganjuk. Peneliti yakin, bahwa dengan menerapkan E - Learning, maka pembelajaran bahasa Indonesia akan menjadi lebih menyenangkan. Di samping itu, para siswa dalam belajar menjadi lebih bergairah, aktif berdiskusi, dan lebih kreatif dalam mengembangkan proses berfikir mereka.

\section{METODE PENELITIAN}

Penelitian dilaksanakan pada siswa kelas VII SMP Negeri 1 Nganjuk dengan menggunakan pola kerja kolaboratif. Prosedur penelitian untuk satu siklus dirancang seperti pada bagan berikut:

$$
\mathrm{Ra} \quad------>\mathrm{T} \quad \text {------->O } \mathrm{O} \quad \text {-----.> R } \quad \text {-------.>Pk }
$$

(Abdullah Sholihin LPMP, Bahan Diklat KTI, 2006)

Ra : Rancangan awal

$\mathrm{T}$ : Tindakan Pertama

O : Observasi

$\mathrm{R}$ : Refleksi

$\mathrm{Pk}$ : Perencanaan kembali untuk siklus berikutnya

Jumlah siklus yang direncanakan ada 2 siklus. Masing-masing siklus terdiri dari dua kali tatap muka. Adapun tindakan (rancangan penelitian) ini secara garis besar adalah seabagai berikut : Pelaksanaan Kegiatan Siklus I Guru mempersiapkan materi pemebelajaran yang akan diunggah melalui youtube. Pembentukan kelompok kerja/diskusi dan memberi kesempatan berinteraksi antarteman via WA Setiap kelompok (terdiri dari 5 siswa) mengambil satu lot untuk menentukan soal yang akan dikerjakan. Pemberian inspirasi 
pada siswa tentang materi kemampuan menulis teks hasil observasi Setiap kelompok mendiskusikan soal-soal yang ditugasi dan membagi tugas kepada setiap anggota kelompok. Masing-masing anggota kelompok ditugasi mengerjakan soal lain secara individu.

Langkah tindakan yang dilakukan adalah : Membuat RP yang berisi materi kemampuan menulis teks hasil observasi .Membagi kelompok untuk mengerjakan soal yang telah disediakan. Menyiapkan materi dan tugas latihan kelompok .Pemberian inspirasi pada siswa tentang materi kemampuan menulis teks hasil observasi Siswa mengerjakan soal secara kelompok. Kelompok melaporkan hasil diskusi kerja kelompok. Tanya jawab untuk membahas materi yang masih belum dipahami siswa melalui WA Secara individu siswa mengerjakan/menulis teks hasil observasi sebagai tes akhir siklus. Merayakan/ memberi penghargaan pada siswa yang aktif menjawab dengan benar. Refleksi (penyampaian kelemahan/kesalahan-kesalahan hasil kerja kelompok) Pelaksanaan Tindakan Siklus II Siklus ini ditujukan untuk melatih siswa bekerja dengan kelompoknya. Rencana tindakannya adalah : Analisis hasil siklus I Menambah pengetahuan tentang cara menulis teks hasil observasi Pemberian inspirasi terhadap siswa terkait dengan kemampuan menulis teks hasil observasi Menambah pembelajaran tentang kemampuan menulis teks hasil observasi Pelaksanaan diskusi kelompok bersama dengan soal beda. Mengerjakan soal menulis teks hasil observasi secara mandiri Merayakan.Refleksi Langkah tindakan siklus II ini adalah : Membuat RP yang bermuatan materi kemampuan menulis teks hasil observasi Menyiapkan tugas kerja mandiri dalam mengerjakan soal dan pemberian inspirasi pada siswa.Pelaksanaan pengerjaan soal menulis teks hasil observasi Pembahasan hasil tugas mandiri Merayakan Tes akhir siklus II, simpulan,dilanjutkan refleksi. Instrumen Penelitian Instrumen penelitian ini menggunakan:Lembar soal tes akhir siklus mandiri yang harus dilaporkan setelah berakhirnya kegiatan siklus. Format pengamatan keaktifan diskusi siswa. Format pengamatan keaktifan guru. Teknik Pengumpulan Data Teknik pengumpulan data yang digunakan dalam Penelitian Tindakan Kelas (PTK) ini adalah sebagai berikut:U ntuk kegiatan awal teknik yang digunakan adalah studi dokumentasi terhadap kegiatan tes awal materi pokok menjelaskan cara menulis teks hasil observasi. Untuk siklus-siklus selanjutnya teknik yang digunakan adalah observasi dengan menggunakan lembar pengamatan dari teman sekelompok dan studi dokumentasi berupa hasil keaktifan siswa dalam diskusi. Mendokumentasikan hasil tes akhir siklus I dan II. Memberikan tanggapan/ kesimpulan atas hasil yang dicapai siswa. Teknik dan Pedoman Analisis Data Mengingat jenis penelitian ini adalah penelitian deskriptif, yaitu "studi untuk menemukan fakta dengan interpretasi yang tepat" (Nazir, 2011), dan data variabel tunggal dari menulis teks hasil observasi yang dikumpulkan berupa data kuantitatif (berupa angka-angka) dan data kualitatif (berupa kalimat dan kategori-kategori) maka teknik analisis data yang digunakan ada dua macam:Pemberian skor tes akhir siklus Rentang nilai yang digunakan adalah angka $0-100$. Nilai akhir diperoleh dari jumlah seluruh skor yang dihasilkan siswa, dengan ketentuan untuk tes subjektif ( 2 soal), tiap soal diberi skor 1-5 dengan bobot 10 untuk masing-masing soal untuk data kuantitatif teknik analisis data yang digunakan adalah mean dan persentase (\%) dengan rumus persentase keberhasilan adalah:

$\mathrm{P}=\frac{f}{N} x 100 \%$

Keterangan:

$\mathrm{P}=$ Angka persentase

$\mathrm{f}=$ frekuensi yang sedang dicari persentasenya

$\mathrm{N}=$ jumlah frekuensi/banyaknya individu

(Sugiyono, 2008).

Persentase keberhasilan minimal yang diharapkan adalah $85 \%$ dari jumlah siswa bisa menulis teks hasil observasi. Untuk data kualitatif teknik analisis data yang digunakan adalah teknik analisis membandingkan, yaitu dengan membandingkan antara kondisi harapan dan 
kenyataan (Arikunto, 2002). Pedoman analisis data untuk masing-masing aspek keberhasilan adalah Pedoman analisis nilai rata-rata kelas dapat dilihat pada tabel ini

Tabel 1. Pedoman Analisis Nilai Rata-rata Kelas

\begin{tabular}{|c|c|c|c|}
\hline No & Interval & Kategori & Keterangan tindakan \\
\hline 1 & $91-100$ & Amat baik & Amat berhasil, siklus dihentikan \\
\hline 2 & $75-90$ & Baik & Berhasil, siklus dihentikan \\
\hline 3 & $60-74$ & Cukup & Cukup berhasil, siklus dilanjutkan \\
\hline 4 & $40-59$ & Kurang & Kurang berhasil, siklus dilanjutkan \\
\hline 5 & $<40$ & Amat kurang & Amat kurang, siklus dilanjutkan \\
\hline
\end{tabular}

Sumber data: hasil olahan peneliti

Pedoman analisis persentase ketuntasan hasil belajarPedoman analisis nilai persentase ketuntasan hasil belajar dapat dilihat pada tabel di bawah ini.

Tabel 2. Pedoman Analisis Nilai Persentase Ketuntasan Hasil Belajar

\begin{tabular}{|c|c|c|c|}
\hline No & Interval & Kategori & Keterangan tindakan \\
\hline 1 & $91-100 \%$ & Amat baik & Amat berhasil, siklus dihentikan \\
\hline 2 & $75-90 \%$ & Baik & Berhasil, siklus dihentikan \\
\hline 3 & $60-74 \%$ & Cukup & Cukup berhasil, siklus dilanjutkan \\
\hline 4 & $40-59 \%$ & Kurang & Kurang berhasil, siklus dilanjutkan \\
\hline 5 & $<40 \%$ & $\begin{array}{c}\text { Amat } \\
\text { kurang }\end{array}$ & $\begin{array}{c}\text { Amat kurang berhasil, siklus } \\
\text { dilanjutkan }\end{array}$ \\
\hline
\end{tabular}

Pedoman analisis aktivitas siswa dalam pembelajaran Nilai aktivitas siswa dalam pembelajaran ditentukan berikut:

Tabel 3. Pedoman Analisis persentase keberhasilan aktivitas belajar siswa

\begin{tabular}{|c|c|c|c|}
\hline No & Interval & Kategori & Keterangan tindakan \\
\hline 1 & $91-100 \%$ & Amat baik & Amat berhasil, siklus dihentikan \\
\hline 2 & $75-90 \%$ & Baik & Berhasil, siklus dihentikan \\
\hline 3 & $60-74 \%$ & Cukup & Cukup berhasil, siklus dilanjutkan \\
\hline 4 & $40-59 \%$ & Kurang & Kurang berhasil, siklus dilanjutkan \\
\hline 5 & $<40 \%$ & $\begin{array}{c}\text { Amat } \\
\text { kurang }\end{array}$ & $\begin{array}{c}\text { Amat kurang berhasil, siklus } \\
\text { dilanjutkan }\end{array}$ \\
\hline
\end{tabular}

Pedoman analisis aktivitas guru dalam pembelajaran Nilai aktivitas guru dalam pembelajaran ditentukan berikut: jika nilai yang dicapai guru $=5=$ amat baik, $4=$ baik, $3=$ cukup, $2=$ kurang, dan $1=$ sangat kurang baik. Pedoman analisisnya berdasarkan perhitungan berikut: Jika nilai maksimal $=5$, dan nilai minimal $=1$, maka rangenya $=5-1=4$. Jika besar interval kelas ditetapkan $=5$ maka dengan menggunakan range jumlah kelasnya $=4 / 5=0.8$.

Tabel 4. Pedoman Analisis Nilai Aktivitas Guru dalam Pembelajaran

\begin{tabular}{|c|c|c|c|}
\hline No & Interval Nilai & Kategori & Keterangan tindakan \\
\hline 1 & $4,3-5,0$ & Amat baik & Amat berhasil, siklus dihentikan \\
\hline 2 & $3,5-4,2$ & Baik & Berhasil, siklus dihentikan \\
\hline 3 & $2,7-3,4$ & Cukup & Cukup berhasil, siklus dilanjutkan \\
\hline 4 & $1,90-2,6$ & Kurang & Kurang berhasil, siklus dilanjutkan \\
\hline 5 & $1,0-1,8$ & $\begin{array}{c}\text { Amat } \\
\text { kurang }\end{array}$ & $\begin{array}{c}\text { Amat kurang berhasil, siklus } \\
\text { dilanjutkan }\end{array}$ \\
\hline
\end{tabular}

Indikator Keberhasilan Penelitian ini dinyatakan berhasil bila bisa memenuhi indikator keberhasilan sebagai berikut:Adanya kenaikan persentase hasil belajar bahasa 
Indonesia.Persentase keberhasilan minimal yang diharapkan adalah 85\% siswa bisa menulis teks hasil observasi .Tercapainya peningkatan Prestasi Belajar Bahasa Indonesia (Materi Pokok menulis teks hasil observasi) siswa dengan nilai rata-rata minimal 75,00.Tercapainya kegiatan pembelajaran yang menarik bagi guru dan siswa sehingga bisa memenuhi target sesuai kompetensi yang diharapkan.

\section{HASIL DAN PEMBAHASAN}

Data Nilai Kegiatan Awal Berdasarkan hasil kegiatan sebelum penelitian yang diperoleh melalui kegiatan pemberian tugas materi pokok menulis teks hasil observasi, data nilai dapat disajikan sebagai berikut :

Tabel 5. Hasil Tes Kegiatan Awal

\begin{tabular}{|c|l|c|}
\hline NO & \multicolumn{1}{|c|}{ ASPEK } & KET. \\
\hline 1 & Rata-rata kelas & 66,56 \\
\hline 2 & Yang Berhasil & 8 \\
\hline 3 & Persentase Keberhasilan & $25 \%$ \\
\hline
\end{tabular}

Sumber : Data Hasil Olahan Peneliti, 2020.

Dari data di atas dapat dilaporkan bahwa :Nilai rata-rata kelas untuk pembelajaran menulis teks hasil observasi masih di bawah rata-rata standar minimal prestasi yang diharapkan, yakni masih bawah 75,00 atau baru mencapai 66,56. Berarti masih jauh dari keberhasilan minimal (masih kurang 8,44 nilai)Jumlah siswa yang berhasil hanya 8 siswa dengan persentase jumlah siswa yang berhasil hanya mencapai $25 \%$, dengan rincian perolehan hasil :2 siswa memperoleh nilai 85 (antara 75-90) B (tuntas) 2 siswa memperoleh nilai 80 (antara 75-90) B (tuntas) 4 siswa memperoleh nilai 75 (antara 75-90) B (tuntas) 12 siswa memperoleh nilai 70 (antara 65-74) C (tidak tuntas) 6 siswa memperoleh nilai 60 (antara 65-74) C (tidak tuntas 6 siswa memperoleh nilai 50 (antara 50-64) D (tidak tuntas) Hasil Kegiatan Siklus I Perencanaan Hasil yang dicapai pada tahap ini: Ada simpulan hasil refleksi data awal. Ada RPP untuk melakukan perbaikan pada siklus I dan II Adanya instrumen penelitian berupa soal tes akhir siklus, angket respon siswa terhadap pembelajaran, dan format pengamatan keaktifan siswa dalam diskusi. Pelaksanaan Hasil kegiatan pada tahap pelaksanaan ini berupa jawaban tes akhir siklus I dari siswa yang dikoreksi bersama pengamat. Setelah diadakan koreksi, maka hasil belajar siswa terhadap pembelajaran bahasa Indonesia dengan materi pokok menulis teks hasil observasi adalah sebagai berikut:

Tabel 6. Hasil Tes Akhir Siklus I

\begin{tabular}{|c|l|c|}
\hline NO & \multicolumn{1}{|c|}{ ASPEK } & KET. \\
\hline 1 & Rata-rata kelas & 73,13 \\
\hline 2 & Yang Berhasil & 17 \\
\hline 3 & Persentase Keberhasilan & $53,13 \%$ \\
\hline
\end{tabular}

Sumber : Data Hasil Olahan Peneliti, 2020

Berdasarkan tabel di atas dapat dideskripsikan sebagai berikut: Hasil dari pelaksanaan penelitian tindakan pada siklus I ini berdasarkan tabel di atas dapat dinyatakan bahwa ada peningkatan hasil belajar siswa dari data awal berata-rata 66,56 menjadi 73,13 berarti ada kenaikan nilai sebesar 6,57. Rincian hasil belajar siswa kelas VII dalam menulis teks hasil observasi adalah sebagai berikut: 2 siswa memperoleh nilai 90 (antara 75-90) B (tuntas) 4 siswa memperoleh nilai 85 (antara 75-90) B (tuntas) 11 siswa memperoleh nilai 80 (antara 7590) B (tuntas) 8 siswa memperoleh nilai 70 (antara 65-74) C (tidak tuntas) 2 siswa memperoleh nilai 60 (antara 65-74) C (tidak tuntas) 2 siswa memperoleh nilai 50 (antara 5064) D (tidak tuntas) Perkembangan nilai siklus I dibanding dengan nilai kegiatan sebelumnya (prasiklus) menunjukkan peningkatan sebagai berikut : Nilai rata-rata meningkat 6,57 nilai (dari 66,56/data awal menjadi 73,13). Jumlah siswa berhasil meningkat 9 siswa (dari 8 
/prasiklus menjadi 17 siswa). Persentase keberhasilan meningkat 28,13\% (dari 25\% prasiklus menjadi 53,13\%) Observasi Hasil pengamatan pengamat dapat dilihat pada tabel berikut ini:

Tabel 7. Hasil Keaktifan Diskusi Siswa Pada Siklus I

\begin{tabular}{|l|l|c|c|c|c|}
\hline NO & \multicolumn{1}{|c|}{ Nama } & $\begin{array}{c}\text { Jlm. } \\
\text { Siswa } \\
\text { data awal }\end{array}$ & $\begin{array}{c}\text { Persen } \\
\text { tase data } \\
\text { awal }\end{array}$ & $\begin{array}{c}\text { JML } \\
\text { SISWA } \\
\text { Siklus } \\
\text { I }\end{array}$ & $\begin{array}{c}\text { PERSEN } \\
\text { TASE } \\
\text { Siklus I }\end{array}$ \\
\hline 1 & Aktif memunculkan ide & 4 & $12,5 \%$ & 20 & $62,5 \%$ \\
2 & Jumlah siswa bertanya & 4 & $12,5 \%$ & 12 & $37,5 \%$ \\
3 & Berperan aktif dalam & 6 & $18,8 \%$ & 30 & $93,8 \%$ \\
& diskusi & & & & \\
5 & Aktif mendengarkan & 8 & $25,0 \%$ & 32 & $100 \%$ \\
6 & Aktif mengerjakan tugas & 8 & $25,0 \%$ & 30 & $93,8 \%$ \\
7 & Antusias siswa dalam PBM & 8 & $25,0 \%$ & 28 & $87,5 \%$ \\
\hline & Kerja sama & 10 & $31,5 \%$ & 26 & $81,3 \%$ \\
\hline
\end{tabular}

Sumber Data : Hasil Olahan Pengamat, 2020.

Berdasarkan tabel hasil pengamatan pada siklus I di atas, keaktifan siswa dalam belajar melalui E - Learning menunjukkan kenaikan persentase sebesar 58\% dari data awal 21,5\% menjadi 79,5\% siswa telah berani melakukan diskusi dengan baik. Refleksi Berdasarkan hasil analisis data di atas dapat direfleksikan bahwa :"Penerapan E-Learning yang dikembangkan pada siklus I belum berhasil, sehingga belum berpengaruh positif terhadap kemampuan siswa dalam menulis teks hasil observasi siswa kelas VII SMP Negeri 1 Nganjuk " Dengan demikian perlu ada revisi sebagai langkah tindak lanjut pengembangan penggunaan E-Learning. Pada siklus I ini jumlah siswa berhasil baru mencapai 53,13\% (17 siswa). Sedangkan yang belum berhasil masih 46,87\% (15 siswa). Kelima belas siswa tersebut ketidakberhasilannya karena proses pemahaman terhadap materi pokok. Oleh sebab itu pada siklus II perlu adanya penambahan/penajaman teori tentang cara memahami dan mendeskripsikan hal-hal yang ada dalam materi pokok, serta cara menulis teks hasil observasi yang baik.

Di samping refleksi hasil belajar berupa prestasi belajar bahasa Indonesia, pada kegiatan pembelajaran telah tampak berbagai keaktifan siswa. Sudah 79,5\% siswa aktif berkerja sama dalam kelompoknya. Hasil Kegiatan Siklus II Perencanaan Hasil yang dicapai pada tahap ini: Ada simpulan hasil refleksi siklus I.Ada penyempurnaan RPP untuk siklus II Pelaksanaan Setelah diadakan kegiatan berupa : Pemantapan cara menulis teks hasil observasi Pengoptimalan diskusi kelompok. Nilai siswa dalam menulis teks hasil observasi mengalami peningkatan. Hal ini dapat dilihat pada sajian tabel berikut ini:

Tabel 8. Hasil Tes Akhir Siklus II

\begin{tabular}{|c|l|c|}
\hline NO & \multicolumn{1}{|c|}{ ASPEK } & KET. \\
\hline 1 & Rata-rata kelas & 81,56 \\
\hline 2 & Yang Berhasil & 30 \\
\hline 3 & Persentase Keberhasilan & $93,75 \%$ \\
\hline
\end{tabular}

Sumber : Data Hasil Olahan Peneliti, 2020.

Berdasarkan tabel tersebut dapat dideskripsikan hasilnya sebagai berikut: Hasil dari pelaksanaan penelitian tindakan pada siklus II ini berdasarkan tabel di atas dapat dinyatakan bahwa Ada peningkatan prestasi belajar siswa dari siklus I berata-rata 73,13 menjadi 81,56 berarti ada kenaikan nilai sebesar 8,43 nilai.Rincian hasil belajar siswa kelas VII SMP Negeri 1 Nganjuk dalam menulis teks hasil observasi adalah sebagai berikut: 8 siswa memperoleh nilai 90 (antara 75-90) B (tuntas) 6 siswa memperoleh nilai 85 (antara 75-90) B (tuntas) 8 
siswa memperoleh nilai 80 (antara 75-90) B (tuntas) 8 siswa memperoleh nilai 75 (antara 7590) B (tuntas) 2 siswa memperoleh nilai 70 (antara 65-74) C (tidak tuntas).

Perkembangan nilai siklus II dibanding dengan nilai siklus I menunjukkan peningkatan sebagai berikut : Nilai rata-rata meningkat 8,43 (dari 73,13 /hasil siklus I menjadi 81,56).Jumlah siswa berhasil meningkat 13 siswa (dari 17/ siklus I menjadi 30 siswa).Persentase keberhasilan meningkat 40,62\% (dari $53,13 \%$ / siklus I menjadi $93,75 \%$ ) Observasi Selain hasil kegiatan berupa perstasi belajar (angka-angka), terdapat hasil pengamatan dari pengamat berupa keaktifan diskusi siswa. Hasil pengamatan keaktifan siswa meningkat daripada keaktifan siswa pada siklus II Hasil pengamatan pengamat dapat dilihat pada tabel berikut ini:

Tabel 9. Hasil Keaktifan Diskusi Siswa Pada Siklus II

\begin{tabular}{|c|c|c|c|c|c|}
\hline NO & ASPEK & $\begin{array}{l}\text { JML } \\
\text { SISWA } \\
\text { Siklus I }\end{array}$ & $\begin{array}{l}\text { PERSE } \\
\text { NTASE } \\
\text { Siklus I }\end{array}$ & $\begin{array}{l}\text { JML } \\
\text { SISWA } \\
\text { Siklus } \\
\text { II }\end{array}$ & $\begin{array}{l}\text { PERSE } \\
\text { NTASE } \\
\text { Siklus } \\
\text { II }\end{array}$ \\
\hline 1 & Aktif memunculkan ide & 20 & $62,5 \%$ & 28 & $87,5 \%$ \\
\hline 2 & Jumlah siswa bertanya & 12 & $37,5 \%$ & 24 & $75 \%$ \\
\hline 3 & Berperan aktif dalam diskusi & 30 & $93,8 \%$ & 31 & $96,9 \%$ \\
\hline 4 & Aktif mendengarkan & 32 & $100 \%$ & 32 & $100 \%$ \\
\hline 5 & Aktif mengerjakan tugas & 30 & $93,8 \%$ & 32 & $100 \%$ \\
\hline 6 & Antusias siswa dalam PBM & 28 & $87,5 \%$ & 32 & $100 \%$ \\
\hline \multirow[t]{2}{*}{7} & Kerja sama & 26 & $81,3 \%$ & 30 & $93,8 \%$ \\
\hline & Rata-rata & & $79,5 \%$ & & $93,3 \%$ \\
\hline
\end{tabular}

Sumber: Olahan Pengamat, 2020

Berdasarkan hasil pengamatan pada siklus II , kualitas belajar melalui $E$ - Learning menunjukkan kenaikan persentase sebesar 13,8\% dari data siklus I 79,5\% menjadi 93,3\% siswa telah berani melakukan diskusi dengan baik. Refleksi Berdasarkan hasil analisis di atas dapat direfleksikan bahwa :" Penerapan E-Learning yang dikembangkan pada siklus II sudah berhasil maksimal walaupun dengan nilai rata-rata tidak terlalu tinggi , sehingga sudah sangat berpengaruh positif terhadap kemampuan menulis teks hasil observasi pada siswa kelas VII SMP Negeri 1 Nganjuk ." Dengan demikian tidak perlu ada revisi lagi sebagai langkah tindak lanjut pengembangan penggunaan E-Learning. Pada siklus II ini jumlah siswa berhasil sudah mencapai 93,75\% (30 siswa). Hasil Pengamatan Keaktifan Guru Untuk mengetahui Aktivitas guru dalam pembelajaran saat penelitian ini berlangsung, hal yang harus diamati, yaitu: kesesuaian RPP dengan pelaksanaan, pra pembelajaran, kegiatan inti, dan penutup, upaya pemberian motivasi, dan pengelolaan kelas.Berdasarkan hasil pengamatan yang dilakukan pengamat adalah sebagai berikut :

Tabel 10 Hasil Pengamatan Aktivitas Guru

\begin{tabular}{|c|l|c|c|c|}
\hline No & \multicolumn{1}{|c|}{ Aspek } & Prasiklus & Siklus I & Siklus II \\
\hline A & $\begin{array}{l}\text { Kesesuaian RPP dengan } \\
\text { pelaksanaan }\end{array}$ & & & \\
\hline 1 & Pembelajaran & & & \\
\hline & a. Pengecekan kesiapan kelas & 4 & 4 & 5 \\
\hline & b. Appersepsi & 3 & 5 & 5 \\
\hline 2 & Kegiatan Inti & & & \\
\hline & a. Penguasaan materi & 3 & 5 & 5 \\
\hline & b. Strategi pembelajaran & 3 & 4 & 5 \\
\hline & c. Penggunaan bahasa & & & 4 \\
\hline 3 & Penutup & & & \\
\hline
\end{tabular}




\begin{tabular}{|c|l|c|c|c|}
\hline & a. Refleksi/rangkuman & 4 & 5 & 5 \\
\hline & b. Tindak lanjut & 4 & 4 & 4 \\
\hline \multirow{2}{*}{ B } & $\begin{array}{l}\text { Pemberian Motivasi kepada } \\
\text { Siswa }\end{array}$ & 4 & 5 & 5 \\
\hline C & Pengelolaan Kelas & 4 & 4 & 5 \\
\hline & Jumlah nilai & 33 & 36 & 43 \\
\hline & Rata-rata & 3,67 & 4 & 4,78 \\
\hline
\end{tabular}

Keterangan: Hasil Observasi Pengamat yang diolah Keterangan: $5=$ amat baik, $4=$ baik, 3 cukup 2 kurang 1 sangat kurang Dari hasil hitungan tersebut dapat dideskripsikan bahwa: (1) Selalu terjadi peningkatan aktivitas guru dalam pembelajaran pada setiap siklus.; (2) Kenaikan aktivitas guru dari siklus I ke siklus II sebesar 0,78, sedangkan dari prasiklus (data awal, 3,67) ke siklus II $(4,78)$ meningkat sebesar 1,11; dan (3) Berdasarkan tabel 4, angka 4,78 dinyatakan dengan kriteria amat baik.Dengan demikian dapat dikatakan bahwa aktivitas guru tergolong amat tinggi (Guru sangat aktif/ sangat antusias dalam PBM)

Pembahasan Seluruh Siklus Berdasarkan hasil perhitungan pada siklus I dan II di atas, pekembangan hasil belajar bahasa Indonesia materi pokok menulis teks hasil observasi tersebut dapat dilihat pada tabel berikut ini:

Tabel 11. Perkembangan Hasil Belajar bahasa Indonesia menulis teks hasil observasi Siswa Kelas VII SMP Negeri 1 Nganjuk

\begin{tabular}{|c|l|c|c|c|}
\hline \multirow{2}{*}{ NO } & \multicolumn{1}{|c|}{ ASPEK } & $\begin{array}{c}\text { DATA } \\
\text { AWAL }\end{array}$ & $\begin{array}{c}\text { SIKLUS } \\
\text { I }\end{array}$ & $\begin{array}{c}\text { SIKLUS } \\
\text { II }\end{array}$ \\
\hline 1 & Nilai Rata-rata kelas & 66,56 & 73,13 & 81,56 \\
\hline 2 & Jumlah siswa berhasil & 8 & 17 & 30 \\
\hline 3 & Persentase keberhasilan (\%) & $25 \%$ & $53,13 \%$ & $93,75 \%$ \\
\hline 4 & Aktivitas kegiatan siswa (\%) & $21,5 \%$ & $79,5 \%$ & $93,3 \%$ \\
\hline 5 & Aktivitas kegiatan guru & 3,67 & 4 & 4,78 \\
\hline
\end{tabular}

Sumber data: Olahan Peneliti, Hasil tes akhir siklus, 2020.

Berdasarkan tabel di atas dapat dideskripsikan bahwa : Perkembangan nilai rata-rata kelas, jumlah siswa, dan persentase keberhasilan siswa dalam menulis teks hasil observasi pada setiap siklusnya selalu mengalami kenaikan.Peningkatan yang terjadi dari data awal sampai siklus II sbb.: Nilai rata-rata meningkat 15 (dari 66,56 /hasil prasiklus menjadi 81,56 pada siklus II). Jumlah siswa berhasil meningkat 22 siswa (dari 8 / prasiklus menjadi 30 siswa pada siklus II). Persentase keberhasilan meningkat $68,75 \%$ (dari $25 \% /$ prasiklus menjadi $93,75 \%$ pada siklus II) Nilai aktivitas kegiatan siswa dalam pembelajaran meningkat $71,8 \%$ dari $(21,5 \% /$ prasiklus menjadi $93,3 \%$ pada siklus II) Nilai aktivitas kegiatan guru dalam pembelajaran meningkat sebesar 1,11 dari prasiklus (data awal, 3,67) ke siklus II $(4,78)$. Berdasarkan hasil perhitungan pada data awal, siklus I, dan II di atas dapat direfleksikan bahwa hasil akhir (siklus II) sebagai berikut: (1) Nilai rata-rata kelas mencapai 81,56 jika dikonsultasikan terhadap tabel 1 dinyatakan berhasil (baik), siklus dihentikan; (2) Persentase keberhasilan siswa mencapai 93,75\% jika dikonsul-tasikan thd. tabel 2 dinyatakan amat baik, siklus dihentikan; (3) Persentase keberhasilan aktivitas siswa mencapai 93,3\% jika dikonsultasikan terhadap tabel 3 dinyatakan berhasil (baik), siklus bisa dihentikan; dan (4) Nilai rata-rata aktivitas guru mencapai 4,78 dan dinyatakan amat berhasil (amat baik), siklus bisa dihentikan.Berdasarkan hasil refleksi di atas dapat dinyatakan bahwa penerapan $E-$ Learning yang dikembangkan pada siklus II sudah berhasil dengan baik dan siklus bisa dihentikan, karena pada keempat aspek indikator keberhasilan penelitian sudah mencapai di atas rata-rata yang diisyaratkan pada indikator keberhasilan penelitian ini. 


\section{KESIMPULAN}

Berdasarkan rumusan masalah, deskripsi hasil analisis, dan refleksi hasil penelitian tersebut maka dapat disimpulkan bahwa : Melalui penerapan E-Learning, maka kemampuan menulis teks hasil observasi pada Siswa Kelas VII SMP Negeri 1 Nganjuk dapat meningkat dari sebelumnya. Peningkatan kemampuan menulis teks hasil observasi sampai pada siklus II dapat dilaporkan bahwa: (1) Nilai rata-rata kelas mencapai 81,56; (2) Persentase keberhasilan siswa mencapai 93,75\%; (3) Persentase keberhasilan aktivitas siswa mencapai 93,3\%. E-Learning dapat meningkatkan aktivitas belajar siswa Kelas VII SMP Negeri 1 Nganjuk.

\section{DAFTAR PUSTAKA}

Abdullah, Sholihin. (2006). Diklat LPMP. Surabaya: LPMP Jatim.

Arikunto, Suharsini. (2002). Metodologi Penelitian Suatu Pendekatan Proposal. Jakarta: PT. Rineka Cipta.

Arikunto, Suharsini. (2016). Strategi Pembelajaran Sastra Pada Era Globalisasi. Yogyakarta: Azzagrafika

Fanny, A. M. (2019). Pengaruh Pembelajaran E-Learning Terhadap Hasil Belajar Mahasiswa PGSD Pada Mata Kuliah Konsep IPS Lanjut. INVENTA: Jurnal Pendidikan Guru Sekolah Dasar. 3(1), 130-135.

Hartanto, Wiwin. (2016). Penggunaan E-learning Sebagai Media Pembelajaran. Jurnal Pendidikan Ekonomi: Jurnal Ilmiah Ilmu Pendidikan, Ilmu Ekonomi dan Ilmu Sosial. 10(1), 1-18

Nasution, S. (2003). Berbagai Pendekatan dalam Proses Belajar dan Mengajar. Jakarta: Bumi Aksara.

Nazir, Mohammad. (2011). Metode Penelitian. Jakarta: Ghalia Indonesia.

Sugiyono. (2008). Metode Penelitian Kuantitatif Kualitatif dan R\&D. Bandung :

ALFABETA 